\title{
Ecological risk assessment of metals and metalloid in bottom sediments of water reservoir located in the key anthropogenic "hot spot" area (Poland)
}

\author{
Malwina Tytła ${ }^{1} \cdot$ Maciej Kostecki ${ }^{1}$
}

Received: 9 January 2018 / Accepted: 15 February 2019 / Published online: 1 March 2019

(c) The Author(s) 2019

\begin{abstract}
Study was aimed to assess the potential ecological risk of nine metals ( $\mathrm{Al}, \mathrm{Cd}, \mathrm{Cr}, \mathrm{Cu}, \mathrm{Fe}, \mathrm{Mn}, \mathrm{Ni}, \mathrm{Pb}$, and $\mathrm{Zn}$ ) and one metalloid (As) in bottom sediments of the Dzierżno Duże Reservoir located in the key anthropogenic "hot spot" area-Upper Silesian Industrial Region (Poland). Sediments were collected in seven sampling sites, along the main axis of a reservoir. Statistical analysis revealed a significant correlation $(p<0.05)$ between the potentially toxic elements, which indicated that they plausibly originate from the same source of contamination or have a similar accumulation behavior. Several indices were used to assess ecological risk associated with examined elements, i.e., Enrichment Factor, Geoaccumulation Index, Contamination Factor, Potential Ecological Risk Factor, Probable Effect Concentration, Threshold Effect Concentration, Degree of Contamination and Risk Index. The values of analyzed indices indicate that sediments are highly to extremely highly contaminated, especially by $\mathrm{Cd}, \mathrm{Pb}, \mathrm{Zn}$, and $\mathrm{As}$, which simultaneously pose the highest ecological risk. The results of Cluster Analysis (CA) and Principal Component Analysis (PCA) indicate that $\mathrm{Cd}, \mathrm{Cr}, \mathrm{Fe}, \mathrm{Ni}, \mathrm{Pb}, \mathrm{Zn}$, and As in the bottom sediments are most likely of anthropogenic origin, while $\mathrm{Mn}$ rather from natural sources. The obtained results confirm the usefulness of different indices in assessing the ecological condition of water bodies and prove that the problem of toxic elements contamination in bottom sediments of the Dzierżno Duże Reservoir poses a serious environmental threat.
\end{abstract}

Keywords Metals and metalloids · Bottom sediments · Ecological risk · Contamination level $\cdot$ Upper Silesian Industrial Region · Dzierżno Duże Reservoir

\section{Introduction}

Metals and metalloids (potentially toxic elements) present in the environment pose a serious threat to human health and living organisms, due to their toxicity, environmental stability, and ease of entry into food chain (Milošković et al. 2013; Baran et al. 2016). The chemical composition of bottom sediments, which are an integral part of aquatic environment, is conditioned by many natural and anthropogenic factors. It results from the geological structure of the catchment,

Malwina Tytła

malwina.tytla@ipis.zabrze.pl

Maciej Kostecki

maciej.kostecki@ipis.zabrze.pl

1 Institute of Environmental Engineering, Polish Academy of Sciences, 34 M. Skłodowska-Curie St, 41-819 Zabrze, Poland land geomorphology, climate conditions, the way of management and use of catchment area, as well as the amount of contaminants reaching surface waters (Smal et al. 2015). The natural sources of metals and metalloids in water bodies are atmospheric inputs, as well as geological weathering of rocks and soil (Ghaleno et al. 2015; Wardhani et al. 2017), but the majority of these toxic elements are of anthropogenic origin (mining, disposal of wastewaters, metal chelates from different industries, use of fertilizers, atmospheric deposition, etc.) (Siebielec et al. 2015; Szydłowski et al. 2017). It should be emphasized that only a small pool of free metal or metalloid ions remains dissolved in water, while a large quantity of them are accumulated in the bottom sediments (as a result of adsorption, hydrolysis and co-precipitation processes) (Wardhani et al. 2017). Sediments act both as a sink and source of potentially toxic elements in aquatic ecosystems (Saleem et al. 2015; Devanesan et al. 2017), which may be re-suspended and cause secondary contamination to the water bodies (Wardhani et al. 2017). Moreover, these 
potentially toxic elements may accumulate in the tissues of aquatic organisms and cause various negative effects, associated with limiting of growth, metabolic processes, etc. (Milošković et al. 2013). There are some studies focused on the bioaccumulation of toxic elements in aquatic organisms. For example, Rzymski et al. (2014) indicate a high bioaccumulation of $\mathrm{Cd}, \mathrm{Cr}$, and $\mathrm{Cu}$ in different bivalve species, as well as high concentrations of $\mathrm{Cd}$ and $\mathrm{Pb}$ in leaves of selected macrophyte, living in the artificial water body (Malta Reservoir, Poland). Moreover, positive correlations were found between $\mathrm{Pb}$ concentration in sediments and tissues of all examined bivalve species. While, Wu et al. (2014) show the moderate to very high ecological risk to humans from fish, because of elevated levels of $\mathrm{Hg}$ and $\mathrm{Cd}$ concentration in selected water reservoirs (Hongfeng and Baihua Reservoirs, China).

Therefore, the assessment of metals and metalloids concentration in the sediments of different water bodies may be useful in assessing human impact on the aquatic environment and its ecological state (biota), especially in case of reservoirs located in areas of high industrialization and urbanization. Moreover, to fully assess the level of contamination and ecological risk posed by potentially toxic elements in water bodies, it is necessary to take into account also the ecotoxicological criteria based on the relation between measured concentrations of these elements and observed biological effects.

The Dzierżno Duże Reservoir is located in the Silesian Region (Upper Silesian Industrial Region; GOP), which is one of the most urbanized areas of Poland (Central Europe). This part of country is characterized by great intensity of industrialization, particularly coal mining, metallurgy, energy, heavy industry and transportation, which cause high environmental contamination by metals and metalloids, including those toxic one. Therefore, the chemical composition of bottom sediments in this area depends mainly on the degree of human impact (Baran et al. 2016). The reservoir is supplied with waters of the Kłodnica River, which is one of the most contaminated rivers in Poland. Within Kłodnica catchment, hard coal mines, industrial plants and wastewater treatment plants, etc., are located (Barbusińki and Nocon 2011). It is important to note that properties of toxic elements, i.e., their concentrations, non-biodegradability and toxicity are the major reason for their monitoring in an aquatic environment (Smal et al. 2015). Strong attention should be, therefore, put to ecological state of contaminated water bodies located in Silesian Region, which makes this issue one of the most current research topic in Poland.

Previous studies indicate that bottom sediments from the rivers and artificial reservoirs located in Silesian Region are characterized by potentially higher concentration of toxic elements, compared to other places in Poland and abroad. For example, sediments of the Malta Reservoir, which is located in the northwestern part of Poland (Wielkopolska Region) are characterized by lower concentrations of $\mathrm{Cd}$, $\mathrm{Cr}, \mathrm{Cu}, \mathrm{Fe}, \mathrm{Ni}, \mathrm{Pb}$, and $\mathrm{Zn}$, compared to sediments of the Dzierżno Duże Reservoir (Rzymski et al. 2014; Rzętała 2016). Similar dependence was observed in reservoirs located in other countries, such as in Italy (Pertusillo Reservoir) or Spain (Castilseras Reservoir), where sediments showed lower levels of selected elements, i.e., $\mathrm{Al}$, $\mathrm{As}, \mathrm{Cd}$, $\mathrm{Cu}, \mathrm{Fe}, \mathrm{Pb}$, and $\mathrm{Zn}$ (Colella and D'Orsogna 2014; GarcíaOrdiales et al. 2016), compared to those analyzed in this work.

Therefore, taking into account the above facts, it can be assumed that there is a possibility of existence of high contamination degree and potential ecological risk, associated with the presence of potentially toxic elements in bottom sediments of the Dzierżno Duże Reservoir, which encourage us to comprehensive analysis of these issues. Presented approach may lead to gain more knowledge about the potentially toxic elements, which occurred in the studied bottom sediments, as well as in other water bodies located in the key anthropogenic "hot spot" areas, such as Silesian Region. Due to the fact, that bottom sediments are habitat for many aquatic organisms and also taking into account the possibility of their use in agricultural (as a fertilizer) or as material for ground reclamation, to avoid secondary contamination of the environment, it is very important to know their chemical composition (Bartoszek et al. 2015).

To assess the contamination level and ecological risk of selected toxic elements in sediments of the Dzierżno Duże Reservoir, different indices were used, i.e., related to a single element or to a group of elements. The first group includes: Enrichment Factor (EF), Geoaccumulation Index $\left(I_{\text {geo }}\right)$, Contamination Factor (CF), Potential Ecological Risk Factor (ER), Probable Effect Concentration (PEC), Threshold Effect Concentration (TEC). Whereas, the second one: Degree of Contamination (DC) and Risk Index (RI). Several previous research have shown the usefulness of different groups of indices in the assessment of the sediments contamination level and ecological risk posed by metals and metalloids (Zhao et al. 2012; Ghaleno et al. 2015; Saleem et al. 2015; Baran et al. 2016; Sivakumar et al. 2016). Study on the relationship between different indices allows a more reliable assessment of the risks associated with the presence of potentially toxic elements in aquatic environment, which makes this approach comprehensive. This is particularly important in case of reclamation of water reservoirs, e.g., by removing the backlog of sediments through dredging of reservoir, which may cause a migration of potentially toxic elements accumulated in sediments into the water (Bartoszek et al. 2015).

The aims of this study were (1) to investigate the total concentrations of nine metals $(\mathrm{Al}, \mathrm{Cd}, \mathrm{Cr}, \mathrm{Cu}, \mathrm{Fe}, \mathrm{Mn}, \mathrm{Ni}$, $\mathrm{Pb}, \mathrm{Zn}$ ) and one metalloid (As) in bottom sediments of the 
Dzierżno Duże Reservoir, which are the most commonly analyzed toxic elements in the considered study area, (2) to evaluate the level of sediments contamination, (3) to carry out a comprehensive analysis of the ecological risk connected with the presence of metals and metalloid in bottom sediments, and (4) to demonstrate the usefulness of diverse indices to estimate the real contamination level and ecological risk.

\section{Materials and methods}

\section{Study area}

Dzierżno Duże Reservoir is located in the middle part of the Kłodnica River valley (right-hand tributary of the Odra River), in Silesian Region, Southern Poland $\left(50^{\circ} 22^{\prime} 24^{\prime \prime} \mathrm{N}\right.$; $\left.18^{\circ} 33^{\prime} 25^{\prime \prime} \mathrm{E}\right)$. It lies in the upland area. Moreover, together with the Dzierżno Małe and Pławniowcie Reservoirs, as well as Gliwicki Canal creates the West Water Junction Node (also called the Kłodnica River hydrotechnical system). It plays an important role in water management and in the processes of shaping water quality (Kostecki and Suschka 2013). The map of study area is presented in Fig. 1.

The Dzierżno Duże Reservoir was created in 1964 by introducing waters of the contaminated Kłodnica River into the mine, where previously the backfilling sand was excavated. Currently it is the largest reservoir of this type in Poland. It covers an area of over $6 \mathrm{~km}^{2}$ and has a capacity of $94.0 \mathrm{hm}^{3}$. The average water flow rate is $6.6 \mathrm{~m}^{3} / \mathrm{s}$. The catchment area of the reservoir covers about $545 \mathrm{~km}^{2}$ and is partially owned by the Upper Silesian Industrial Region. The length of the major axis of the reservoir is $5.9 \mathrm{~km}$, maximum width of $1.5 \mathrm{~km}$, and the maximum depth less than $20 \mathrm{~m}$ (average depth of about $15 \mathrm{~m}$ ). The minimum, normal and maximum water levels are $194.5 \mathrm{~m}$ a.s.1., $202.5 \mathrm{~m}$ a.s.1. and $203.5 \mathrm{~m}$ a.s.1., respectively. Moreover, there is an underwater dyke in the reservoir, which divides it into two separate basins, slow down the water flow, and in consequence influence the way of sediments accumulation. The average retention time of water in the reservoir is about 200 days. A complete exchange of water takes 1 month, if so-called high water situation occur ("Program for the reclamation of dam reservoirs in the catchment area of Kłodnica River" 2016).

The main functions of the Dzierżno Duże Reservoir are ensuring the invasive flow of the Kłodnica River, reducing its flood wave, supplying water for the Gliwice Canal (to improving its navigability), protecting biodiversity, supplying the inviolable flow of the lower section of the river (minimum flow that should be maintained), and purifying waters of heavily contaminated river by acting as a "natural" clarifier.

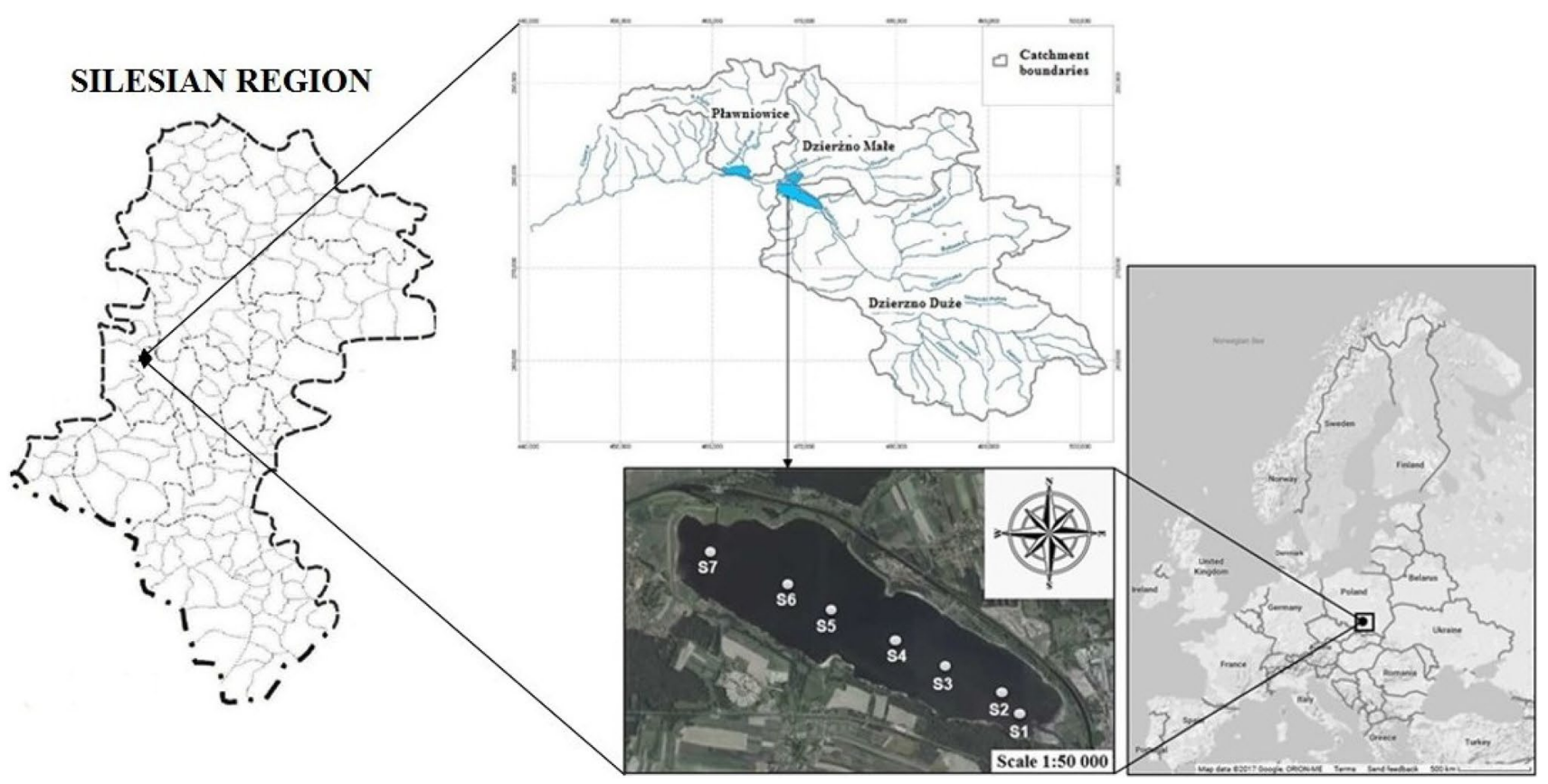

Fig. 1 Location of study area. The map on the left presents the borders of Silesian Region (Southern Poland, Central Europe). The map at the bottom presents the sampling sites at the Dzierżno Duże Reservoir (https://www.google.com/maps). The map on the top presents the catchment area of Dzierżno Duże Reservoir ("Program for the reclamation of dam reservoirs in the catchment area of Kłodnica River"
2016). The map was created using ArcGIS on the basis of Raster Hydrographical Map of Poland (http://www.kzgw.gov.pl/index.php/ $\mathrm{pl} /$; map after modification). The map on the right shows the Europe with borders of Poland (the original source file from: https://www. google.pl/maps/@56.5060646,29.3968922,4z/data=!5m1!1e4?hl=en) 
The urban as well as industrial nature of the Dzierżno Duże Reservoir catchment is reflected by the main forms of land use, where the industrial areas cover-32\%, industrial wasteland areas with agricultural land- $43 \%$, whereas forests-23\% (Rzętała 2016) (Fig. 2). The rapid growth of urbanization and industrial development in the Upper Silesian Industrial Region has resulted in increasing metals and metalloids contamination in the waters and sediments of the Kłodnica River, which had a significant impact on the ecological state of Dzierżno Duże Reservoir. In the study area, the following types of industrial activity can be distinguished: energy sector, production and processing of metals, mineral industry, chemical industry, waste and wastewater management, paper and wood production and processing, intensive livestock production and aquaculture, animal and vegetable products from the food and beverage sector, etc. Different anthropogenic sources in the catchment area of Dzierżno Duże Reservoir enhance potentially toxic elements contamination in sediments. The localization of the main sectors of industrial activity in the Upper Silesian Industrial Region is presented in Fig. 3.

\section{Sampling}

Samples were collected at seven sampling sites (S1-S7) from the surface layer of the sediments (to a depth of $5 \mathrm{~cm}$ ) with the usage of Birge-Ekman sampler. All samples were collected during summer period (August 2016). The sampling sites were located $0.2 \mathrm{~km}, 1 \mathrm{~km}, 2 \mathrm{~km}$, $3 \mathrm{~km}, 4 \mathrm{~km}, 5 \mathrm{~km}$, and $6 \mathrm{~km}$ from the shoreline (S1-S4before the underwater dike, S5-S7-after dike). Due to the asymmetry related to variable reservoir depth, sediments were collected along its main axis from the depth of $0.4 \mathrm{~m}-18 \mathrm{~m}$ (Fig. 1). At each site, three samples were collected, and then well mixed to obtain a representative one. All sediment samples were kept in polyethylene

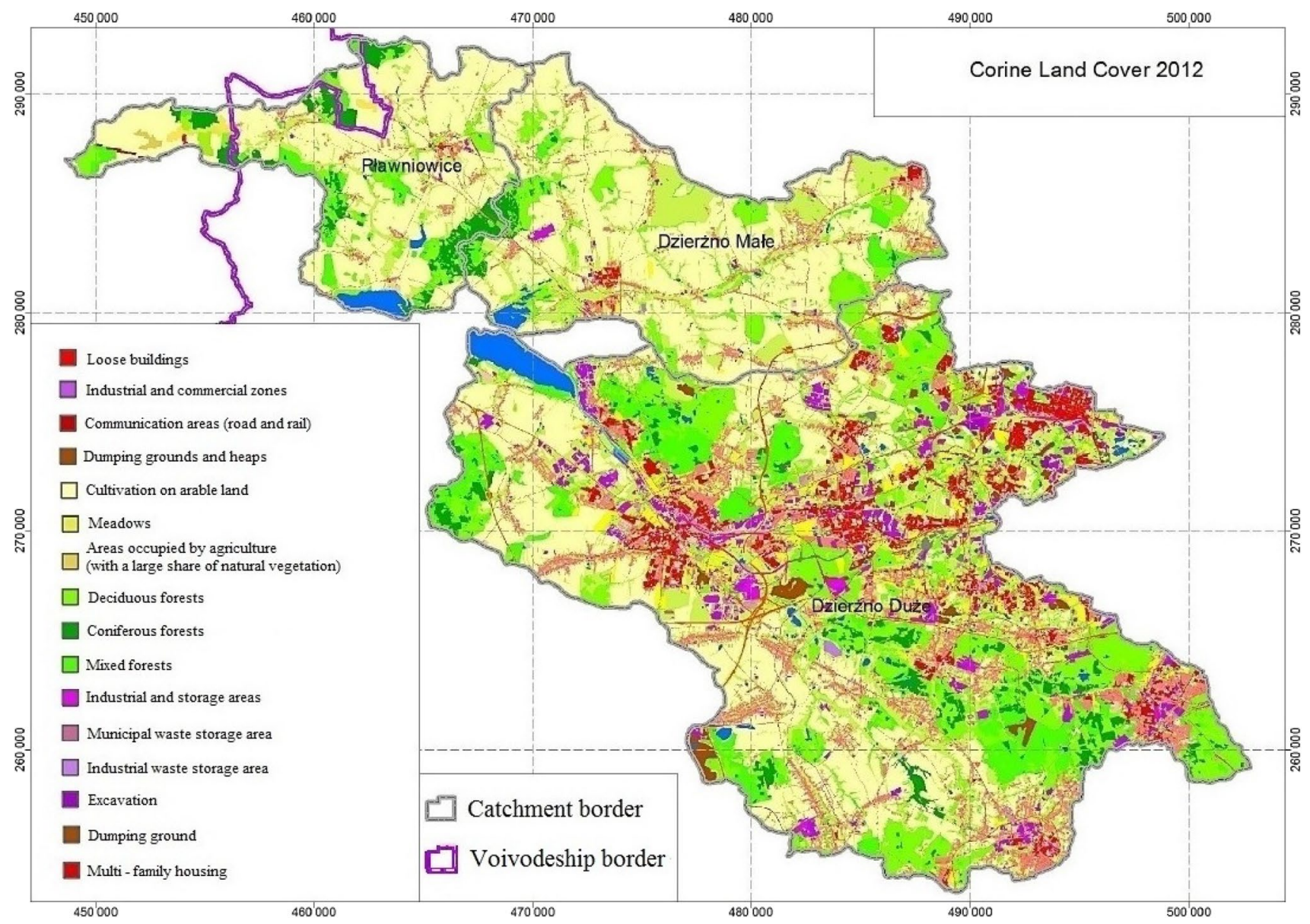

Fig. 2 Land covers in the catchment area of the Kłodnica Riverincluding the catchment of the Dzierżno Duże Reservoir ("Program for the reclamation of dam reservoirs in the catchment area of Kłodnica River" 2016). The map was prepared using database created as part of the project Corine Land Cover 2012 (Corine Land Cover
2012 project in Poland was implemented by the Institute of Geodesy and Cartography and financed by the European Union). The results of the project were obtained from the website of the Chief Inspectorate for Environmental Protection (clc.gios.gov.pl.). The legend on the map was modified 


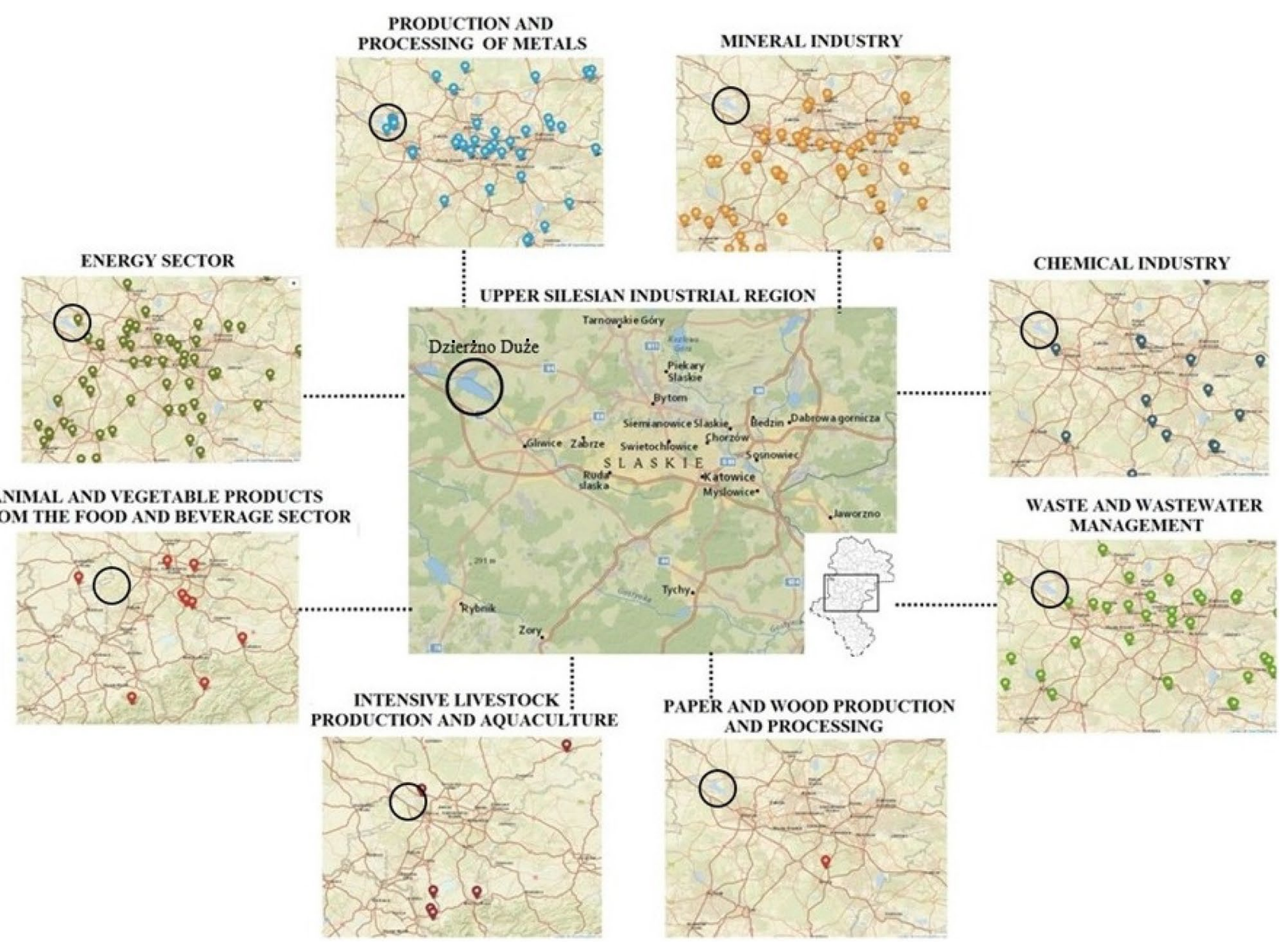

Fig. 3 Industrial activity in the Upper Silesian Industrial Region. The original source files from: http://prtr.ec.europa.eu/\#/industrialactivity (European Environment Agency, EEA) and http://www.arcgis.com/home/webmap/viewer.html

Table 1 Geographical location of the sampling sites

\begin{tabular}{lllc}
\hline Sampling sites & Latitude & Longitude & Depth $(\mathrm{m})$ \\
\hline S1 & $50^{\circ} 354^{\prime} \mathrm{N}$ & $18^{\circ} 601^{\prime} \mathrm{E}$ & 0.4 \\
S2 & $50^{\circ} 357^{\prime} \mathrm{N}$ & $18^{\circ} 597^{\prime} \mathrm{E}$ & 0.8 \\
S3 & $50^{\circ} 362^{\prime} \mathrm{N}$ & $18^{\circ} 584^{\prime} \mathrm{E}$ & 1.1 \\
S4 & $50^{\circ} 365^{\prime} \mathrm{N}$ & $18^{\circ} 574^{\prime} \mathrm{E}$ & 8.0 \\
S5 & $50^{\circ} 368^{\prime} \mathrm{N}$ & $18^{\circ} 564^{\prime} \mathrm{E}$ & 13.0 \\
S6 & $50^{\circ} 370^{\prime} \mathrm{N}$ & $18^{\circ} 558^{\prime} \mathrm{E}$ & 17.0 \\
S7 & $50^{\circ} 373^{\prime} \mathrm{N}$ & $18^{\circ} 543^{\prime} \mathrm{E}$ & 18.0 \\
\hline
\end{tabular}

(HDPE) containers and stored in refrigerator at $4{ }^{\circ} \mathrm{C}$, until the analysis. The sediments were collected once, at the peak of summer stagnation, when the most unfavorable oxygen-thermal conditions prevailed in the reservoir (the possibility of occurrence of conditions, favoring metals release from sediments into the water). Geographical locations and depth of the sampling sites are shown in Table 1.

\section{Analytical procedures}

Potential redox (Eh) and $\mathrm{pH}$ of the sediment samples were measured using Multifunctional Meter CX-401 (Elmetron) and electrodes as in order: ERPt-111 (Hydromet), ERH111 (Hydromet). dry matter (DM) and organic matter (OM) content were determined in accordance with PN-ISO 11465 (1999) "Soil Quality_Determination of dry matter content of soil and water in soil on the basis of dry matter-Weight method". Selected metals and metalloid concentrations in sediments were analyzed by spectrometric methods. The concentrations were presented in $\mathrm{mg} / \mathrm{kg}_{\mathrm{DM}}$.

\section{Sample pretreatment}

The sediment samples were air-dried through exposure to ambient air for $48 \mathrm{~h}$. After that, stones, sticks, etc., were manually removed. The air-dried sediments were milled in a mortar grinder and sieved through a $0.2 \mathrm{~mm}$ sieve. In next step, $0.5 \mathrm{~g}$ of sediment sample was digested with $\mathrm{HNO}_{3}$ and $\mathrm{HCl}$ in Teflon flask. To control the digestion process, blank 
reagent sample with the same amount of acids but without the sediments was used. Obtained solutions were filtered through the fine filters $(0.45 \mu \mathrm{m})$ and diluted with $5 \% \mathrm{HNO}_{3}$ to volume of $50 \mathrm{ml}$. The digestion process was conducted in accordance with PN-EN 13657 (2006) "Characterization of waste. Digestion for subsequent determination of aqua regia soluble portion of elements".

\section{Determination of metals and metalloid concentrations}

Concentrations of the $\mathrm{Al}$ and $\mathrm{Fe}$ in the obtained digests were determined by means of Inductively Coupled Plasma Mass Spectrometry (ICP-MS 6100 DRC-E, PerkinElmer Inc.) in accordance with Institute of Environmental Engineering (Polish Academy of Sciences in Zabrze) own procedure-_The application of inductively coupled plasma mass spectrometry in water quality studies" and PN-EN ISO 17294:2007 "Water quality. Application of inductively coupled plasma mass spectrometry (ICP-MS). Part 1: General guidelines". While, concentrations of $\mathrm{As}, \mathrm{Cd}, \mathrm{Cr}, \mathrm{Cu}, \mathrm{Mn}$, $\mathrm{Ni}, \mathrm{Pb}$, and $\mathrm{Zn}$ were determined using Inductively Coupled Plasma Optical Spectrometry (ICP-OES Optima 2000 DV, PerkinElmer Inc.) in accordance with PN-EN ISO 11885 (2009) "Water quality_Determination of selected elements by Inductively Coupled Plasma Optical Emission Spectrometry (ICP-OES)". All standards were prepared on the day of analysis. The measurements were made in triplicate. The evaluation of uncertainty and precision of the analytical methods were not confirmed by the certified reference materials.

\section{The contamination degree and ecological risk assessment}

The contamination level and potential ecological risk of selected toxic elements in bottom sediments of Dzierżno Duże Reservoir were calculated by the equations shown in Table 2. Due to a varied toxicity of elements depending on the level of their valence state, while assessing the ecological risk, the authors reported the valences of specific elements, i.e., $\mathrm{Al}^{3+}, \mathrm{As}^{(\mathrm{TOT})}, \mathrm{Cd}^{2+}, \mathrm{Cr}^{(\mathrm{TOT})}, \mathrm{Cu}^{2+}, \mathrm{Fe}^{(\mathrm{TOT})}, \mathrm{Mn}^{2+}, \mathrm{Ni}^{2+}$, $\mathrm{Pb}^{2+}, \mathrm{Zn}^{2+}$. In the case of arsenic, chromium and iron, the valence state is given as TOT (Total), as most probable species of these elements are $\mathrm{As}^{3+/ 5+}, \mathrm{Cr}^{3+/ 5+}, \mathrm{Fe}^{2+/ 3+}$ (no speciation analysis was carried out).

\section{Statistical analysis}

All calculations and figures were performed using Statistica 12.0 and Excel 2013. Pearson's correlation coefficients $(r)$ were calculated to determine relationships among different toxic elements in the bottom sediments (the analyzed data had a Gaussian distribution). Cluster Analysis (CA) was used to group elements into meaningful groups (clusters) based on their concentrations at each sampling site (the method by Ward was used for data agglomeration). The Principal Component Analysis (PCA) was carried out to obtain more reliable information about the relationships between the elements in sediments. Data analysis also included mean $(\bar{x})$, coefficient of variation (CV), and standard deviation (SD).

\section{Results and discussion}

\section{Physicochemical characteristics of bottom sediments}

Table 3 presents the statistical summary of $\mathrm{pH}$, Eh, DM, OM, as well as metals and metalloid in bottom sediments of the Dzierżno Duże Reservoir, at various sampling sites (S1-S7). The $\mathrm{pH}$ and Eh values ranged from 7.1 to 7.9 and -349.3 to $-294.1 \mathrm{mV}$, respectively. Both parameters did not show any significant fluctuations depending on the sampling site (pH; CV 4.4\%, Eh; CV 6.4\%). Whereas, DM and OM ranged from 16.0 to $48.9 \%$ and 4.6 to $20.0 \%$, respectively, and characterized by high variability (DM; CV 53.5\%, OM; CV 58.2\%).

The highest overall metals and metalloid concentrations in studied sediments were observed at the sampling site S6 (after the underwater dike), while the lowest at S2 (before the underwater dike). $\mathrm{Fe}, \mathrm{Al}$, and $\mathrm{Zn}$ were found to be the dominant metals. The mean concentrations of potentially toxic elements in the bottom sediments were as follow: $\mathrm{Fe}>$ $\mathrm{Al}>\mathrm{Zn}>\mathrm{Mn}>\mathrm{Pb}>\mathrm{Cu}>\mathrm{Cr}>\mathrm{Ni}>\mathrm{As}>\mathrm{Cd}$, in except of S5 and $\mathrm{S} 7$, where the contents of $\mathrm{Cu}$ and $\mathrm{Pb}$ were in the reverse order. The obtained results indicate that bottom sediments accumulated elements similarly, depending on the location of sampling sites. Moreover, among the considered metals, Mn was characterized by the greatest variability (CV $43.3 \%)$, while $\mathrm{Cr}$ by the lowest one $(\mathrm{CV}=14.7 \%)$.

The highest concentrations of metals and metalloid in sediments (except of $\mathrm{Al}$ and $\mathrm{Cu}$ ) were observed at two sampling sites, i.e., S4 (at $8 \mathrm{~m}$ depth) and S6 (at $17 \mathrm{~m}$ depth). First one was located near to Kłodnica River (before the underwater dike), where waters are rich in these elements (Barbusiński and Nocoń 2011). Whereas, the second one $5 \mathrm{~km}$ from the reservoir shoreline (after the underwater dike). Higher accumulation of toxic elements in this part of reservoir is probably associated with a reduction in flow velocity and sedimentation of suspended solids (SS), which resulted in an increased sorption capacity of these elements. Furthermore, the amount of metals or metalloids in sediments may also increase because of the self-purification processes of the surface waters. As a result of these processes potentially toxic elements migrates from water into 
Table 2 The criteria of contamination level and potential ecological risk of toxic elements in bottom sediments

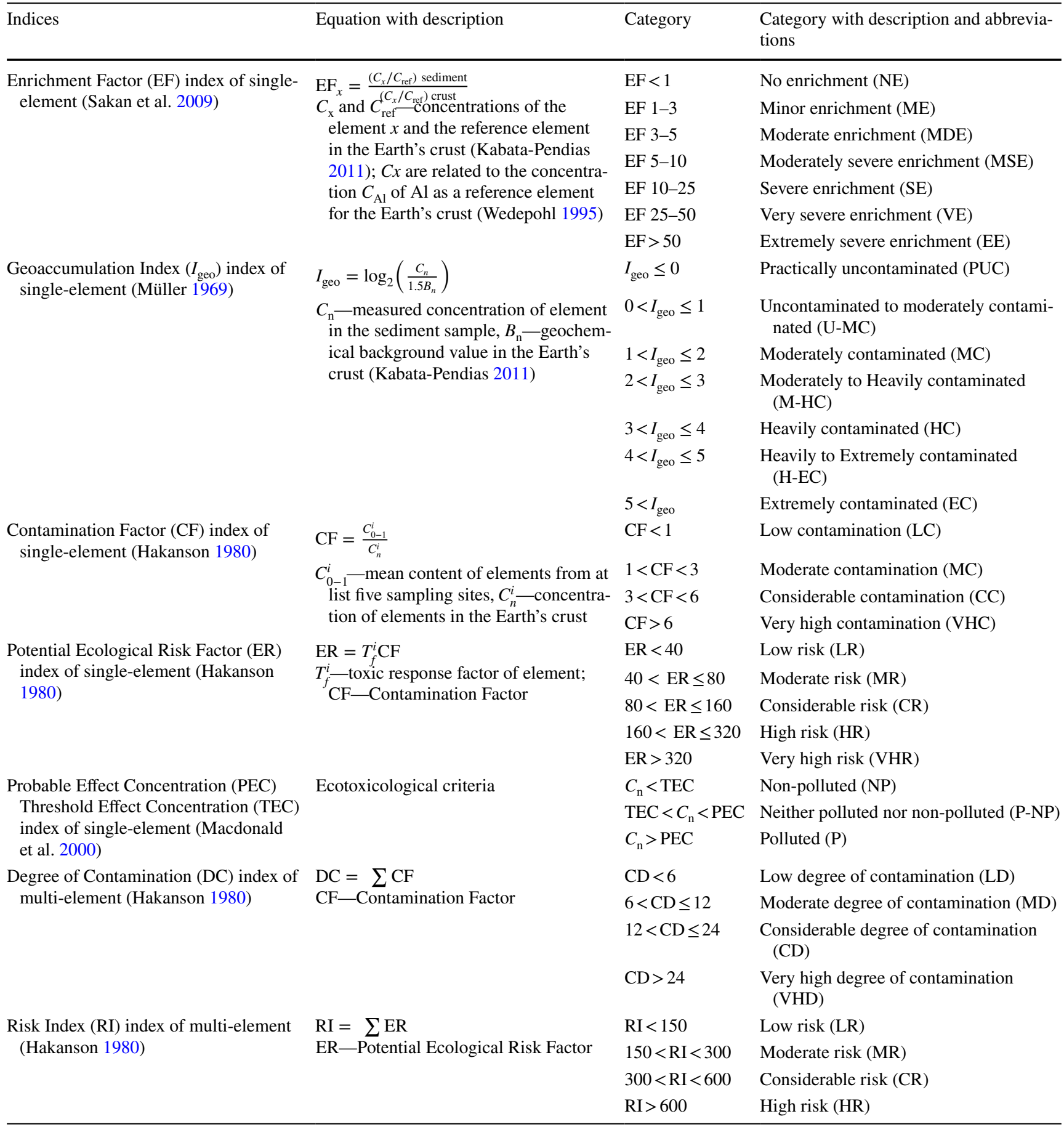

sediments (Barbusiński and Nocoń 2011). However, it was observed, that concentrations of metals and metalloid in studied sediments generally increased with the depth of reservoir (refers to sampling sites) (Fig. 4), but only for Fe and $\mathrm{Ni}$ this relationship was significant $\left(R^{2}>0.6\right)$. Moreover, the analyzed elements were not correlated with other parameters, except of $\mathrm{Cd}, \mathrm{Cr}, \mathrm{Fe}, \mathrm{Zn}$, in case of DM (Table 4). However, there is no certainty that potential release of potentially toxic elements from sediments into water, will not appear. It may occur due to the lowering values of $\mathrm{pH}$ or Eh, resulted from uncontrolled discharges of wastewater, surface runoff, etc. Moreover, to determine the potential mobility, bioavailability and toxicity of examined elements, more extensive studies including the analysis of their chemical forms of occurrence, as well as the temporal variability in sediments characteristics, are necessary. 


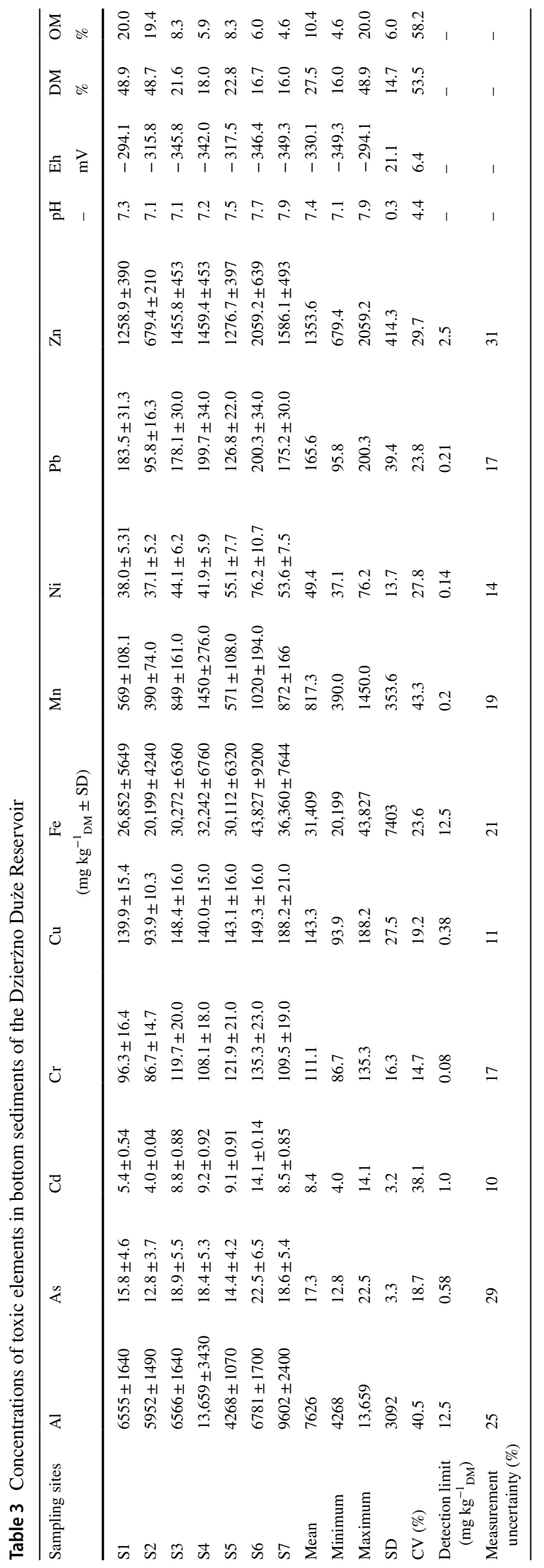


Fig. 4 Metals and metalloid concentrations versus reservoir depth (sampling sites S1-S7)

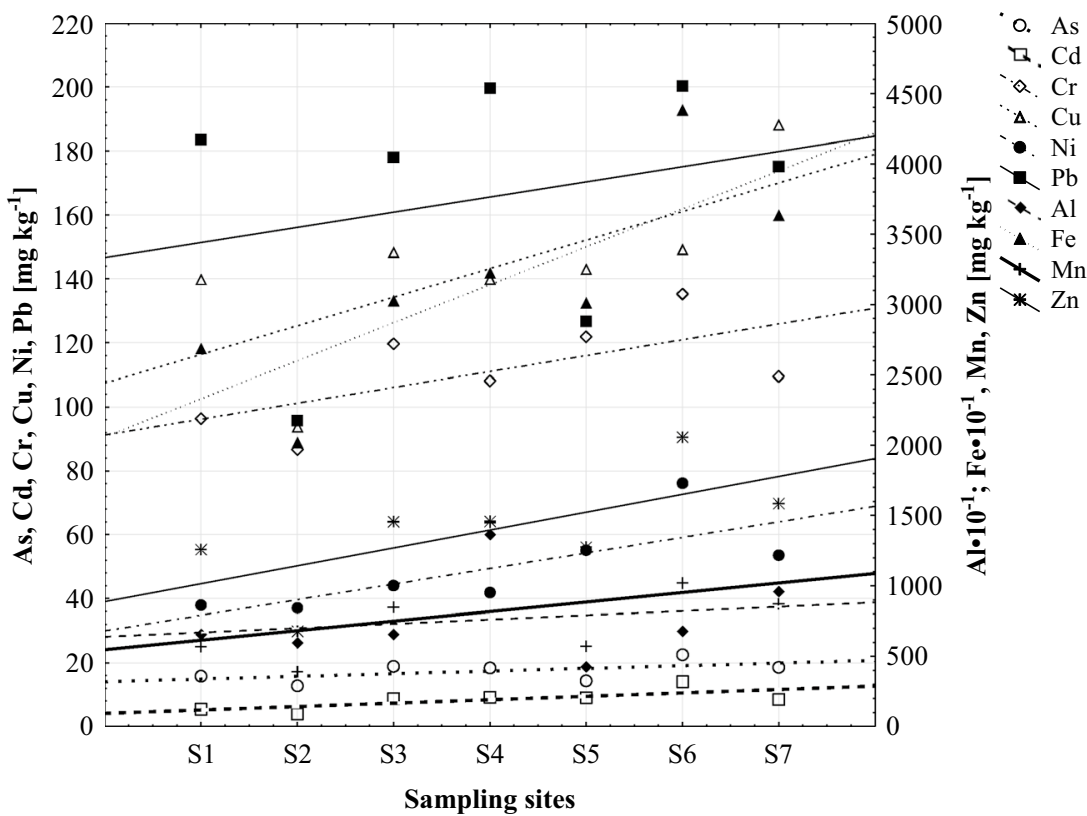

The mean concentrations of toxic elements in studied bottom sediments were compared with the reported studies from Poland and other countries around the world, as presented in Table 5. These data indicate that sediments of the Dzierżno Duże Reservoir are characterized by higher levels of selected elements concentrations compared to other water bodies. Thus, it can be stated, that studied sediments are loaded by potentially toxic elements, which may cause ecological risk.

\section{Assessment of contamination level and potential ecological risk}

The obtained results indicate that, mean concentration of toxic elements in sediment samples exceeded the geochemical background levels. Geochemical quality classification (GQC), includes four classes of sediments, i.e., class I (noncontaminated), class II (moderately contaminated), class III (contaminated), class IV (highly contaminated) (Bojakowska 2001; Siebielec et al. 2015). It was found that $\mathrm{Cd}, \mathrm{Cr}, \mathrm{Cu}$, $\mathrm{Ni}, \mathrm{Pb}$, and $\mathrm{Zn}$ were in the III and IV class (in except of: $\mathrm{Cr}$ and $\mathrm{Ni}$ in $\mathrm{S} 1$, as well as $\mathrm{Cr}, \mathrm{Cu}, \mathrm{Ni}$ and $\mathrm{Pb}$ in $\mathrm{S} 2$ ), while As represents the II class. Thus, it can be concluded that according to the above classification, sediments of Dzierżno Duże Reservoir are highly contaminated by examined metals and metalloid, which was also confirmed by other scientists (Rzętała 2016).

The evaluation of contamination level and ecological risk of selected metals and metalloid in studied bottom sediments were carried out using different indices. The obtained results are shown in Table 6. First group of considered indices is "single-element indices", in which we can distinguish, i.e., the Enrichment Factor. This index indicates the anthropogenic impact on sediments, using normalization element to alleviate the variations produced by heterogeneous sediments (Sakan et al. 2009; Saleem et al. 2015). In this study, aluminum was selected as a reference element for the Earth's crust (consequently, EFAl=1) (Wedepohl 1995). The obtained results showed that studied sediments were moderately to extremely severe enrichment with $\mathrm{Cd}$ (520.4-1651.1), Zn (118.2-335.9), Pb (75.5-153.4) and As (58.0-145.2), regardless of the sampling site. The EF of elements order in the following sequence: $\mathrm{Cd}>\mathrm{Zn}>\mathrm{P}$ $\mathrm{b}>\mathrm{As}>\mathrm{Cu}>\mathrm{Ni}>\mathrm{Cr}>\mathrm{Fe}>\mathrm{Mn}$. In comparison, Baran et al. (2016) indicate, that in sediments from other reservoir situated in the research area (Rybnik Reservoir, Southern Poland), $\mathrm{Cd}$ and $\mathrm{Cu}$ demonstrated extremely sever enrichment. The above results partly confirm our observations. Whereas, other scientists found that sediments from reservoir located in a different region of Poland (Besko Reservoir, Podkarpackie Voivodeship, Southeastern Poland) showed a minor to moderate enrichment for $\mathrm{Cd}, \mathrm{Zn}, \mathrm{Cu}$, $\mathrm{Ni}$, and Cr (Piwińska et al. 2018). Therefore, the above observations revealed different anthropogenic impact on the sediments contamination, depending on the location of reservoir. The second one of considered indices is Geoaccumulation Index computed by comparing the current and pre-industrial concentrations of elements in the Earth's crust (Müller 1969). The values of $I_{\text {geo }}$ revealed that studied sediments were heavily to extremely contaminated by Cd (4.7-6.6), Zn (2.7-4.8), Pb (2.1-3.1) and As (2.2-3.1). Moreover, the $I_{\text {geo }}$ of examined elements were found in the sequence: $\mathrm{Cd}>\mathrm{Zn}>\mathrm{Pb}>\mathrm{As}>\mathrm{Ni}>\mathrm{Cu}>\mathrm{Cr}>\mathrm{Mn}>\mathrm{Fe}>\mathrm{Al}$. The above results were partly confirmed by Zemełka and 


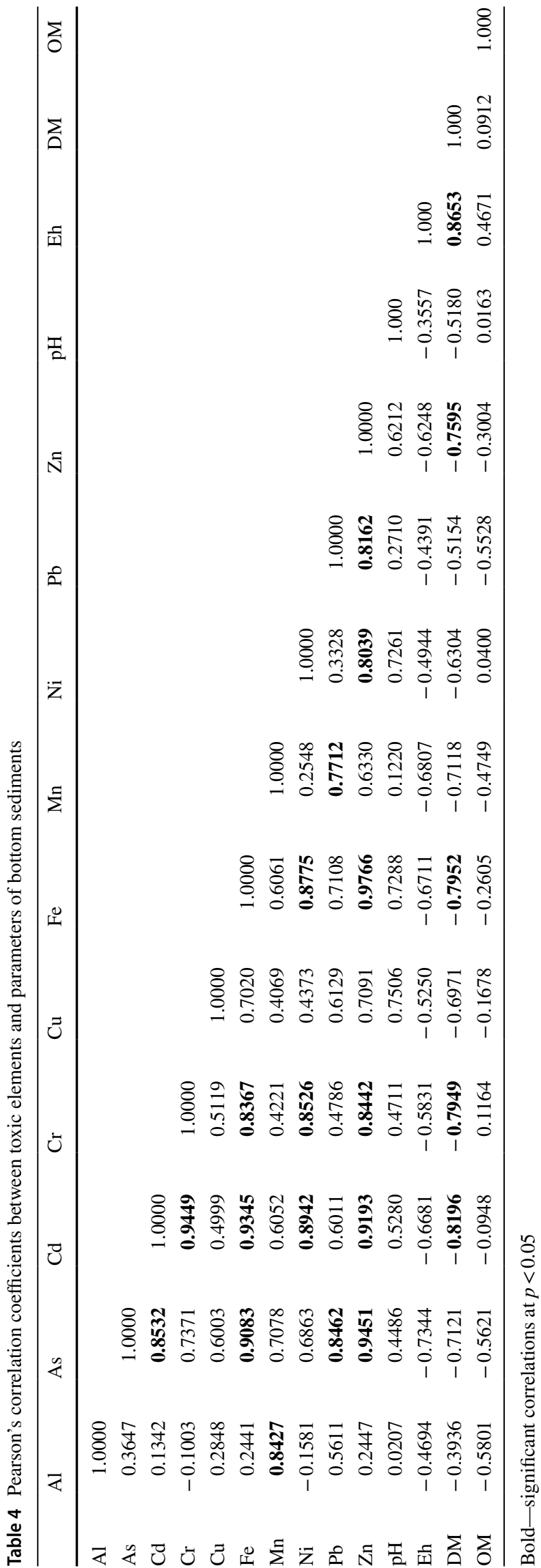

Szalińska (2017), who indicated that Dzierżno Duże Reservoir is heavily to extremely contaminated with $\mathrm{Cd}$, as well as moderately to heavily with $\mathrm{Pb}$ and $\mathrm{Zn}$. Unfortunately, the above work includes only five of eight examined metals $(\mathrm{Cd}, \mathrm{Cr}, \mathrm{Cu}, \mathrm{Pb}, \mathrm{Zn})$. Moreover, also values of the Contamination Factor (Hakanson 1980) confirmed that studied sediments were very highly contaminated with $\mathrm{Cd}$, $\mathrm{Zn}, \mathrm{Pb}$, and $\mathrm{As}(\mathrm{CF}>6)$. The $\mathrm{CF}$ of elements formed the following series in descending order: $\mathrm{Cd}>\mathrm{Zn}>\mathrm{Pb}>\mathrm{As}$ $>\mathrm{Cu}>\mathrm{Ni}>\mathrm{Cr}>\mathrm{Fe}>\mathrm{Mn}>\mathrm{Al}$. The above observations are in good agreement with the results obtained by Rzętała (2016) who indicate, that studied sediments are very highly to moderately contaminated with $\mathrm{Cd}>\mathrm{Cu}>\mathrm{Zn}>\mathrm{As}>\mathrm{Cr}$. In contradiction to our study, the same scientist has shown that in the case of sediments from other reservoir located in short distance from Silesian Region (Otmuchów Reservoir, Opolskie Voivodeship, Southern Poland), the main source of contamination was arsenic. Furthermore, it was also found that according to Potential Ecological Risk Factor calculated by Hakanson (1980); Cd, As (except of S2 and S5) and $\mathrm{Pb}$ (except of $\mathrm{S} 2$ and $\mathrm{S} 7$ ) posed the highest, considerable and moderate potential ecological risk, respectively, whereas other elements posed low risk $(\mathrm{ER}<40)$. The ER for examined elements was found in the following order: $\mathrm{Cd}>\mathrm{As}>\mathrm{Pb}>\mathrm{Zn}>\mathrm{Cu}>\mathrm{Ni}>\mathrm{Cr}>\mathrm{Mn}$ (classification does not include concentration of $\mathrm{Al}$ and $\mathrm{Fe}$ ). In contradiction to our observations, other scientists such as Baran et al. (2016) or Szedłowski et al. (2017) indicated moderately to low risk posed by $\mathrm{Cd}>\mathrm{Cu}>\mathrm{Pb}>\mathrm{Cr}>\mathrm{Zn}$ (Rybnik Reservoir, Southern Poland) and $\mathrm{Ni}>\mathrm{Cd}>\mathrm{Pb}>\mathrm{Cu}>\mathrm{Cr}>\mathrm{Zn}$ (Stare Czarnowo, Zachodniopomorskie Voivodeship, Northwestern Poland), respectively. The above results confirmed that sediments of the Dzierżno Duże Reservoir cause higher ecological risk than sediments from other water bodies in the country. Moreover, risk assessment was also carried out using the ecotoxicological criteria, i.e., Probable Effect Concentration and Threshold Effect Concentration (Macdonald et al. 2000; Baran and Tarnawski 2015). This approach is based on the relation between measured concentrations of elements and observed biological effects (classification does not include $\mathrm{Al}$ concentration). We found that depending on the sampling site, mean concentrations of $\mathrm{Cd}, \mathrm{Pb}, \mathrm{Zn}, \mathrm{Mn}$, $\mathrm{Ni}, \mathrm{Cr}, \mathrm{Cu}$, and $\mathrm{Fe}$ exceeded PEC limit values, which confirmed high contamination of studied sediments with these elements. This means, that they cause an adverse effect on aquatic organisms. Whereas, the concentrations of remaining elements were higher than the TEC but lower than PEC values, which means that they do not pose a threat to the living organisms. In comparison to our experiment, Dąbrowska (2011) indicated that concentrations of $\mathrm{Cd}, \mathrm{Zn}$, and $\mathrm{Pb}$ in sediments of the Kozłowa Góra Reservoir located close to the Dzierżno Duże Reservoir (Silesian Region, Southern Poland) exceeded PEC values. Whereas, Baran and 


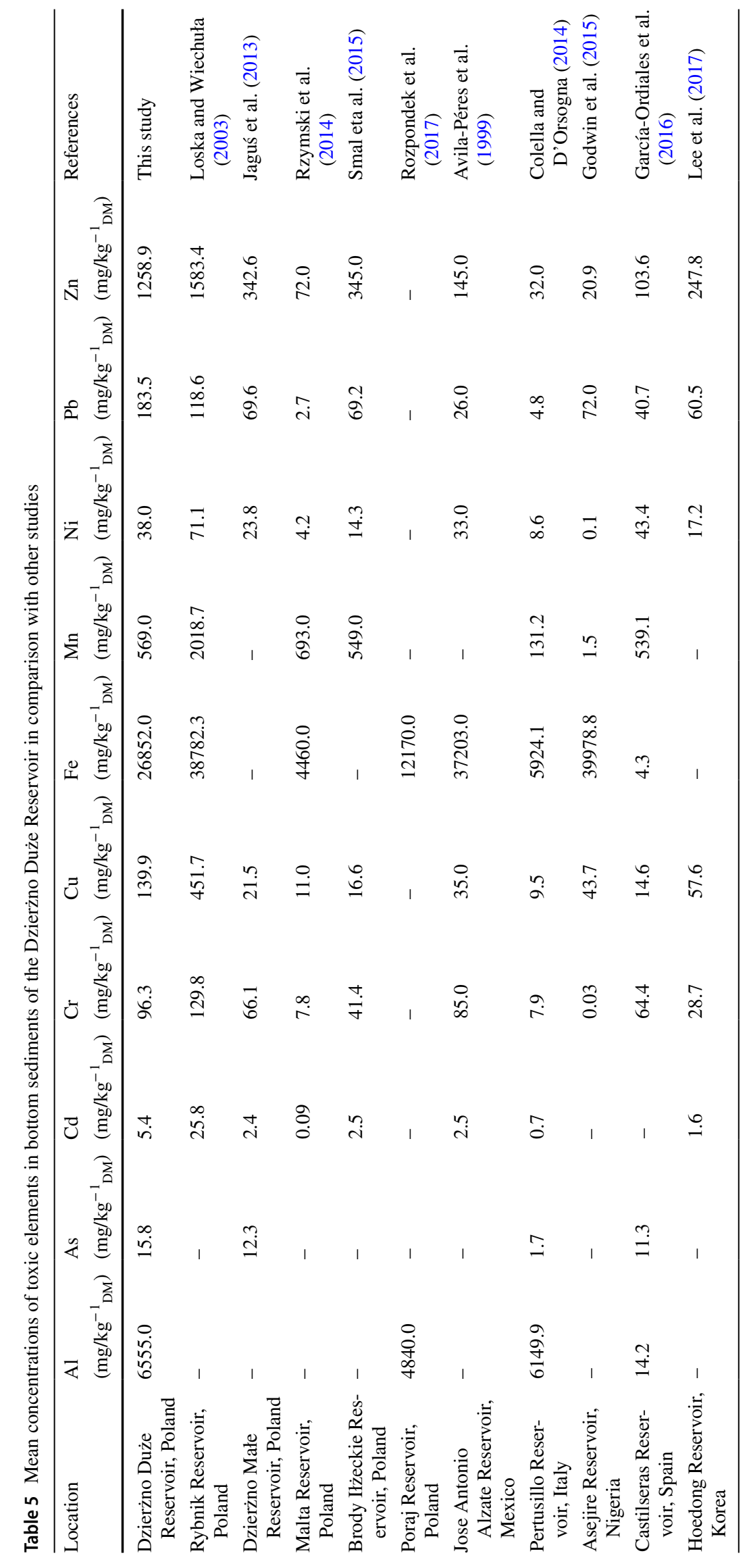


Table 6 Contamination and ecological risk of toxic elements

\begin{tabular}{|c|c|c|c|c|c|c|c|c|c|c|c|c|}
\hline & Metal & $\mathrm{EF}$ & & $I_{\mathrm{geo}}$ & & $\mathrm{CF}$ & & ER & & PEC/TEC & DC & RI \\
\hline \multirow[t]{10}{*}{$\mathrm{S} 1$} & $\mathrm{Al}$ & 1.0 & - & -4.1 & PUC & 0.1 & $\mathrm{LC}$ & - & - & - & 100.0 VHD & 1811.7 HR \\
\hline & As & 103.7 & $\mathbf{E E}$ & 2.5 & M-HC & 8.8 & VHC & 87.8 & CR & P-NP & & \\
\hline & $\mathrm{Cd}$ & 637.9 & EE & 5.2 & EC & 54.0 & VHC & 1620.0 & VHR & $\mathbf{P}$ & & \\
\hline & $\mathrm{Cr}$ & 11.4 & SE & -0.6 & PUC & 1.0 & $\mathrm{MC}$ & 1.9 & LR & P-NP & & \\
\hline & $\mathrm{Cu}$ & 30.1 & VE & 0.8 & U-MC & 2.5 & $\mathrm{MC}$ & 12.7 & LR & P-NP & & \\
\hline & $\mathrm{Fe}$ & 10.3 & SE & -0.8 & PUC & 0.9 & $\mathrm{LC}$ & - & - & P-NP & & \\
\hline & $\mathrm{Mn}$ & 7.5 & MSE & -1.2 & PUC & 0.6 & $\mathrm{LC}$ & 0.6 & LR & P-NP & & \\
\hline & $\mathrm{Ni}$ & 22.4 & SE & 0.3 & U-MC & 1.9 & $\mathrm{MC}$ & 9.5 & LR & P-NP & & \\
\hline & $\mathrm{Pb}$ & 144.5 & $\mathbf{E E}$ & 3.1 & HC & 12.2 & VHC & 61.2 & MR & $\mathbf{P}$ & & \\
\hline & $\mathrm{Zn}$ & 212.5 & EE & 3.6 & HC & 18.0 & VHC & 18.0 & LR & $\mathbf{P}$ & & \\
\hline \multirow[t]{10}{*}{$\mathrm{S} 2$} & $\mathrm{Al}$ & 1.0 & - & -4.3 & PUC & 0.1 & $\mathrm{LC}$ & - & - & - & 68.8 VHD & 1332.9 HR \\
\hline & As & 92.5 & EE & 2.2 & $\mathrm{MC}$ & 7.1 & VHC & 71.1 & MR & P-NP & & \\
\hline & $\mathrm{Cd}$ & 520.4 & $\mathbf{E E}$ & 4.7 & H-EC & 40.0 & VHC & 1200.0 & VHR & $\mathbf{P}$ & & \\
\hline & $\mathrm{Cr}$ & 11.3 & SE & -0.8 & PUC & 0.9 & $\mathrm{LC}$ & 1.7 & LR & P-NP & & \\
\hline & $\mathrm{Cu}$ & 22.2 & SE & 0.2 & U-MC & 1.7 & $\mathrm{MC}$ & 8.5 & LR & P-NP & & \\
\hline & $\mathrm{Fe}$ & 8.5 & MSE & -1.2 & PUC & 0.7 & $\mathrm{LC}$ & - & - & P-NP & & \\
\hline & $\mathrm{Mn}$ & 5.6 & MSE & -1.8 & PUC & 0.4 & $\mathrm{LC}$ & 0.4 & LR & P-NP & & \\
\hline & $\mathrm{Ni}$ & 24.7 & $\mathbf{S E}$ & 0.3 & U-MC & 1.9 & $\mathrm{MC}$ & 9.5 & LR & P-NP & & \\
\hline & $\mathrm{Pb}$ & 83.1 & $\mathbf{E E}$ & 2.1 & $\mathrm{MC}$ & 6.4 & VHC & 31.9 & LR & P-NP & & \\
\hline & $\mathrm{Zn}$ & 126.2 & $\mathbf{E E}$ & 2.7 & $\mathrm{MC}$ & 9.7 & VHC & 9.7 & LR & $\mathbf{P}$ & & \\
\hline \multirow[t]{10}{*}{ S3 } & $\mathrm{Al}$ & 1.0 & - & -4.1 & PUC & 0.1 & $\mathrm{LC}$ & - & - & - & 139.3 VHD & $2853.0 \mathbf{H R}$ \\
\hline & As & 123.8 & $\mathbf{E E}$ & 2.8 & $\mathrm{MC}$ & 10.5 & VHC & 105.0 & CR & P-NP & & \\
\hline & $\mathrm{Cd}$ & 1037.9 & $\mathbf{E E}$ & 5.9 & EC & 88.0 & VHC & 2640.0 & VHR & $\mathbf{P}$ & & \\
\hline & $\mathrm{Cr}$ & 14.1 & SE & -0.3 & PUC & 1.2 & $\mathrm{MC}$ & 2.4 & LR & $\mathbf{P}$ & & \\
\hline & $\mathrm{Cu}$ & 31.8 & VE & 0.8 & U-MC & 2.7 & $\mathrm{MC}$ & 13.5 & LR & P-NP & & \\
\hline & $\mathrm{Fe}$ & 11.6 & SE & -4.1 & PUC & 1.0 & $\mathrm{MC}$ & - & - & P-NP & & \\
\hline & $\mathrm{Mn}$ & 11.1 & SE & -0.7 & PUC & 0.9 & $\mathrm{LC}$ & 0.9 & LR & P-NP & & \\
\hline & $\mathrm{Ni}$ & 26.0 & VE & 0.6 & U-MC & 2.2 & $\mathrm{MC}$ & 11.0 & LR & P-NP & & \\
\hline & $\mathrm{Pb}$ & 140.0 & $\mathbf{E E}$ & 3.1 & HC & 11.9 & VHC & 59.4 & MR & $\mathbf{P}$ & & \\
\hline & $\mathrm{Zn}$ & 245.3 & $\mathbf{E E}$ & 3.8 & HC & 20.8 & VHC & 20.8 & LR & $\mathbf{P}$ & & \\
\hline \multirow[t]{10}{*}{ S4 } & $\mathrm{Al}$ & 1.0 & - & -3.1 & PUC & 0.2 & $\mathrm{LC}$ & - & - & - & 144.9 VHD & 2976.6 HR \\
\hline & As & 58.0 & EE & 2.8 & M-HC & 10.2 & VHC & 102.2 & CR & P-NP & & \\
\hline & $\mathrm{Cd}$ & 521.6 & $\mathbf{E E}$ & 5.9 & EC & 92.0 & VHC & 2760.0 & VHR & $\mathbf{P}$ & & \\
\hline & $\mathrm{Cr}$ & 6.1 & MSE & -0.5 & PUC & 1.1 & $\mathrm{MC}$ & 2.2 & LR & P-NP & & \\
\hline & $\mathrm{Cu}$ & 14.4 & SE & 0.8 & U-MC & 2.5 & $\mathrm{MC}$ & 12.7 & LR & P-NP & & \\
\hline & $\mathrm{Fe}$ & 5.9 & MSE & -0.5 & PUC & 1.0 & $\mathrm{MC}$ & - & - & P-NP & & \\
\hline & $\mathrm{Mn}$ & 9.1 & MSE & 0.1 & U-MC & 1.6 & $\mathrm{LC}$ & 1.6 & LR & $\mathbf{P}$ & & \\
\hline & $\mathrm{Ni}$ & 11.9 & $\mathbf{S E}$ & 0.5 & U-MC & 2.1 & $\mathrm{MC}$ & 10.5 & LR & P-NP & & \\
\hline & $\mathrm{Pb}$ & 75.5 & $\mathbf{E E}$ & 3.1 & HC & 13.3 & VHC & 66.6 & MR & $\mathbf{P}$ & & \\
\hline & $\mathrm{Zn}$ & 118.2 & $\mathbf{E E}$ & 3.8 & $\mathrm{HC}$ & 20.8 & VHC & 20.8 & LR & $\mathbf{P}$ & & \\
\hline \multirow[t]{10}{*}{ S5 } & $\mathrm{Al}$ & 1.0 & - & -4.8 & PUC & 0.1 & LC & - & - & - & 133.9 VHD & 2900.4 HR \\
\hline & As & 145.2 & $\mathbf{E E}$ & 2.4 & M-HC & 8.0 & VHC & 80.0 & MR & P-NP & & \\
\hline & $\mathrm{Cd}$ & 1651.1 & EE & 5.9 & EC & 91.0 & VHC & 2730.0 & VHR & P-NP & & \\
\hline & $\mathrm{Cr}$ & 22.1 & SE & -0.3 & PUC & 1.2 & $\mathrm{MC}$ & 2.4 & LR & P-NP & & \\
\hline & $\mathrm{Cu}$ & 47.2 & VE & 0.8 & U-MC & 2.6 & $\mathrm{MC}$ & 13.0 & LR & P-NP & & \\
\hline & $\mathrm{Fe}$ & 17.7 & SE & -0.6 & PUC & 1.0 & LC & - & - & P-NP & & \\
\hline & $\mathrm{Mn}$ & 11.5 & SE & -1.2 & PUC & 0.6 & $\mathrm{LC}$ & 0.6 & LR & $\mathbf{P}$ & & \\
\hline & $\mathrm{Ni}$ & 50.0 & VE & 0.9 & U-MC & 2.8 & $\mathrm{MC}$ & 13.8 & LR & $\mathbf{P}$ & & \\
\hline & $\mathrm{Pb}$ & 153.4 & $\mathbf{E E}$ & 2.5 & M-HC & 8.5 & VHC & 42.3 & MR & P-NP & & \\
\hline & $\mathrm{Zn}$ & 330.9 & EE & 3.6 & HC & 18.2 & VHC & 18.2 & LR & $\mathbf{P}$ & & \\
\hline
\end{tabular}


Table 6 (continued)

\begin{tabular}{|c|c|c|c|c|c|c|c|c|c|c|c|c|}
\hline & Metal & $\mathrm{EF}$ & & $I_{\mathrm{geo}}$ & & $\mathrm{CF}$ & & ER & & PEC/TEC & DC & RI \\
\hline \multirow[t]{10}{*}{ S6 } & $\mathrm{Al}$ & 1.0 & - & -4.1 & PUC & 0.1 & $\mathrm{LC}$ & - & - & - & 206.8 VHD & 4487.6 HR \\
\hline & As & 142.8 & $\mathbf{E E}$ & 3.1 & HC & 12.5 & VHC & 125.0 & CR & P-NP & & \\
\hline & $\mathrm{Cd}$ & 1610.2 & $\mathbf{E E}$ & 6.6 & EC & 141.0 & VHC & 4230.0 & VHR & $\mathbf{P}$ & & \\
\hline & $\mathrm{Cr}$ & 15.5 & SE & -0.1 & PUC & 1.4 & $\mathrm{MC}$ & 2.7 & LR & $\mathbf{P}$ & & \\
\hline & $\mathrm{Cu}$ & 31.0 & VE & 0.9 & U-MC & 2.7 & $\mathrm{MC}$ & 13.6 & LR & P-NP & & \\
\hline & $\mathrm{Fe}$ & 16.2 & SE & -0.1 & PUC & 1.4 & $\mathrm{MC}$ & - & - & $\mathbf{P}$ & & \\
\hline & $\mathrm{Mn}$ & 12.9 & SE & -0.4 & PUC & 1.1 & $\mathrm{LC}$ & 1.1 & LR & $\mathbf{P}$ & & \\
\hline & $\mathrm{Ni}$ & 43.5 & VE & 1.3 & $\mathrm{MC}$ & 3.8 & $\mathrm{CC}$ & 19.1 & LR & $\mathbf{P}$ & & \\
\hline & $\mathrm{Pb}$ & 152.5 & EE & 3.2 & HC & 13.4 & VHC & 66.8 & MR & $\mathbf{P}$ & & \\
\hline & $\mathrm{Zn}$ & 335.9 & EE & 4.3 & H-EC & 29.4 & VHC & 29.4 & LR & $\mathbf{P}$ & & \\
\hline \multirow[t]{10}{*}{ S7 } & $\mathrm{Al}$ & 1.0 & - & -3.6 & PUC & 0.1 & $\mathrm{LC}$ & - & - & - & 139.1 VHD & 2768.0 HR \\
\hline & As & 83.3 & $\mathbf{E E}$ & 2.8 & M-HC & 10.3 & VHC & 103.3 & CR & P-NP & & \\
\hline & $\mathrm{Cd}$ & 685.3 & EE & 5.8 & EC & 85.0 & VHC & 2550.0 & VHR & $\mathbf{P}$ & & \\
\hline & $\mathrm{Cr}$ & 8.8 & MSE & -0.5 & PUC & 1.1 & $\mathrm{MC}$ & 2.2 & LR & P-NP & & \\
\hline & $\mathrm{Cu}$ & 27.6 & VE & 1.2 & $\mathrm{MC}$ & 3.4 & $\mathrm{CC}$ & 17.1 & LR & $\mathbf{P}$ & & \\
\hline & $\mathrm{Fe}$ & 9.5 & MSE & -0.3 & PUC & 1.2 & $\mathrm{MC}$ & - & - & P-NP & & \\
\hline & $\mathrm{Mn}$ & 7.8 & MSE & -0.6 & PUC & 1.0 & LC & 1.0 & LR & P-NP & & \\
\hline & $\mathrm{Ni}$ & 21.6 & SE & 0.8 & U-MC & 2.7 & $\mathrm{MC}$ & 13.4 & LR & $\mathbf{P}$ & & \\
\hline & $\mathrm{Pb}$ & 94.1 & EE & 3.0 & HC & 11.7 & VHC & 58.3 & MR & $\mathbf{P}$ & & \\
\hline & $\mathrm{Zn}$ & 182.7 & $\mathbf{E E}$ & 3.9 & HC & 22.7 & VHC & 22.7 & LR & $\mathbf{P}$ & & \\
\hline
\end{tabular}

Bold indicates the highest levels

Tarnawski (2015) made a similar observations in relate to $\mathrm{Zn}, \mathrm{Cd}, \mathrm{Cr}$, and $\mathrm{Cu}$ (Rybnik Reservoir, Southern Poland). Thus, it can be concluded, that the above results are in good agreement with those presented here.

The contamination level and ecological risk of examined metals and metalloid in sediments of the Dzierżno Duże Reservoir were also assessing using multi-element indices, i.e., Degree of Contamination and Risk Index (Hakanson 1980). The above indices were used to estimate the overall level of contamination and ecological risk at a given sampling site. The obtained results indicate, that the highest contamination of bottom sediments occurred at sampling site S6 (depth $=17 \mathrm{~m})$, while the lowest at $\mathrm{S} 2($ depth $=0.8 \mathrm{~m})$. The values of DC were extremely high and ranged from 68.8 to 206.8. The above observations were also confirmed by RI values, which was in the range of 1332.0 (S2)-4487.6 (S6). The obtained results indicate that bottom sediments at each sampling sites were found to be highly contaminated with potentially toxic elements, which may cause a high risk to aquatic ecosystem and living organisms. It was revealed that $\mathrm{Cd}, \mathrm{As}, \mathrm{Zn}$, and $\mathrm{Pb}$ pose the greatest threat to the environment, which was consistent with the results obtained using single-element indices. Moreover, high contamination and risk levels suggest that toxic elements in sediments of the Dzierżno Duże Reservoir are most probably of anthropogenic sources. It is most likely related to the location of the reservoir. The middle part of the Kłodnica River valley is one of the most polluted rivers in Silesian Region. However, in this case a more detailed statistical analysis is needed. The similar experiment was made by Baran et al. (2016) who found that bottom sediments from other anthropogenic reservoir (Rybnik Reservoir, Southern Poland) were considerably to highly contaminated by $\mathrm{Zn}, \mathrm{Cd}, \mathrm{Pb}, \mathrm{Ni}, \mathrm{Cu}$, $\mathrm{Cr}$, and $\mathrm{Hg}$ (DC; 14.2-358.0). Whereas, in contradiction to our results, Szydłowsk et al. (2017) showed that: Cd, Co, $\mathrm{Cr}, \mathrm{Cu}, \mathrm{Ni}, \mathrm{Pb}, \mathrm{Zn}$, and $\mathrm{Hg}$ in sediments of the Żelisławiec Reservoir (Zachodniopomorskie Voivodeship, Northwestern Poland), cause only moderate risk to the aquatic ecosystem (RI 164.1). However, it must be emphasized, that the above reservoir is situated in a totally different geographical region of Poland, than the studied one, and characterized with low degree of urbanization and industrialization.

In conclusion, in can be assumed that the contamination level and ecological risk of metals and metalloids in water reservoirs depend on several factors, i.e., sediments characteristics (origin), reservoir location (sources of contamination) and data used as background values (for individual elements).

\section{The source of metals and metalloid contamination}

The high content of metals and metalloids most often occurs in sediments of water reservoirs, to which wastewater from mining and processing of metal ores, as well as large urban 
and industrial centers are discharged (like in the studied area) Trace elements are also introduced to the water bodies as a result of destruction of building materials by atmospheric agents $(\mathrm{Cu}, \mathrm{Cr}, \mathrm{Pb}, \mathrm{Zn})$, corrosion of the water supply and sewage systems (Cd, Zn) (Szydłowski et al. 2017). A considerable amount of potentially toxic elements accumulated in the sediments are introduced to water bodies with wastewater (municipal, industrial, post-mining waters) and with surface runoffs from, i.a., agricultural areas (As, $\mathrm{Cd}, \mathrm{Ni}, \mathrm{Pb}$, $\mathrm{Zn}, \mathrm{Cu})$, urbanized areas or routes communication $(\mathrm{Pb}, \mathrm{Zn}$, Cd) (Siebielec et al. 2015; Ghaleno et al. 2015; Szydłowski et al. 2017). Another sources of metals and metalloids, such as: $\mathrm{As}, \mathrm{Cd}, \mathrm{Fe}, \mathrm{Pb}$ and $\mathrm{Zn}$ are low emission (home furnaces), as well as dust and gas emissions (thermal power plants, mines, steelworks) (García-Ordiales et al. 2016; Szydłowski et al. 2017). Moreover, hard coal mining has an impact on the $\mathrm{Mn}$ and $\mathrm{Fe}$ concentrations due to the discharge of mine wastewater (Barbusiński and Nocoń 2011). The production processes in the food and paper industry also increase the pollution of environment with toxic elements (Szydłowski et al. 2017). It can be concluded that the concentrations of metals and metalloids in bottom sediments of the Dzierżno Duże Reservoir should be combined primarily with the anthropopressure of the surrounding area.

An indication of metals and metalloids sources in the sediments of water reservoirs, constitute a very important aspect of their monitoring and quality control. The traditional statistical approaches such as Pearson's correlation, Cluster Analysis, and Principal Component Analysis are the effective tools for uncovering the contamination sources and have been used by many researchers in studies regarding reservoirs contamination (Loska and Wiechuła 2003; Widziewicz and Loska 2012; Baran et al. 2016). Moreover, as it was mentioned, in this study aluminum has been selected as a normalizing element for the calculation of the sediments EF, which implies that it is of natural origin. For this reason, it was not included in the CA and PCA analysis.

Table 4 presents the results of the Pearson's correlation analysis for toxic elements in bottom sediments of the Dzierżno Duże Reservoir. The obtained results indicate the presence of strong positive correlations between selected elements: As and $\mathrm{Cd}, \mathrm{Fe}, \mathrm{Pb}, \mathrm{Zn} ; \mathrm{Cd}$ and $\mathrm{As}, \mathrm{Cr}, \mathrm{Fe}, \mathrm{Ni}, \mathrm{Zn}$; $\mathrm{Cr}$ and $\mathrm{Fe}, \mathrm{Ni}, \mathrm{Pb}, \mathrm{Zn}$; Fe and $\mathrm{As}, \mathrm{Cd}, \mathrm{Cr}, \mathrm{Ni}, \mathrm{Zn} ; \mathrm{Mn}$ and $\mathrm{Al}$, $\mathrm{Pb}$; $\mathrm{Ni}$ and $\mathrm{Cd}, \mathrm{Cr}, \mathrm{Fe}, \mathrm{Zn} ; \mathrm{Pb}$ and $\mathrm{As}, \mathrm{Mn}, \mathrm{Zn} ; \mathrm{Zn} ; \mathrm{As}, \mathrm{Cd}$, $\mathrm{Fe}, \mathrm{Ni}, \mathrm{Pb}$ and $\mathrm{Al}$ and $\mathrm{Mn}$. Only in the case of $\mathrm{Cu}$, weak but positive correlation with $\mathrm{Fe}, \mathrm{Pb}$ and $\mathrm{Zn}$, was observed. It can be assumed that significant correlations among the above elements may indicate that they possibly have a similar accumulation behavior or originate from the same contaminant sources. Considering the location of the Dzierżno Duże Reservoir, metals and metalloid in bottom sediments are likely of anthropogenic origin. The only exception may constitute $\mathrm{Mn}$, which correlates with Al. Similar observations to the presented one were made by Baran et al. (2016) who found a strong positive correlation between concentrations of $\mathrm{Cd}$, $\mathrm{Cu}, \mathrm{Cr}, \mathrm{Hg}, \mathrm{Ni}, \mathrm{Pb}$ and $\mathrm{Zn}$ in the sediments of reservoir located a short distance from the studied area (Rybnik Reservoir, Southern Poland). It is important to emphasize that both reservoirs are under a strong anthropogenic influence.

Figure 5 presents the results of Cluster Analysis according to which two main groups of potentially toxic elements can be distinguished. First group contains $\mathrm{As}, \mathrm{Cd}, \mathrm{Cr}, \mathrm{Cu}$,

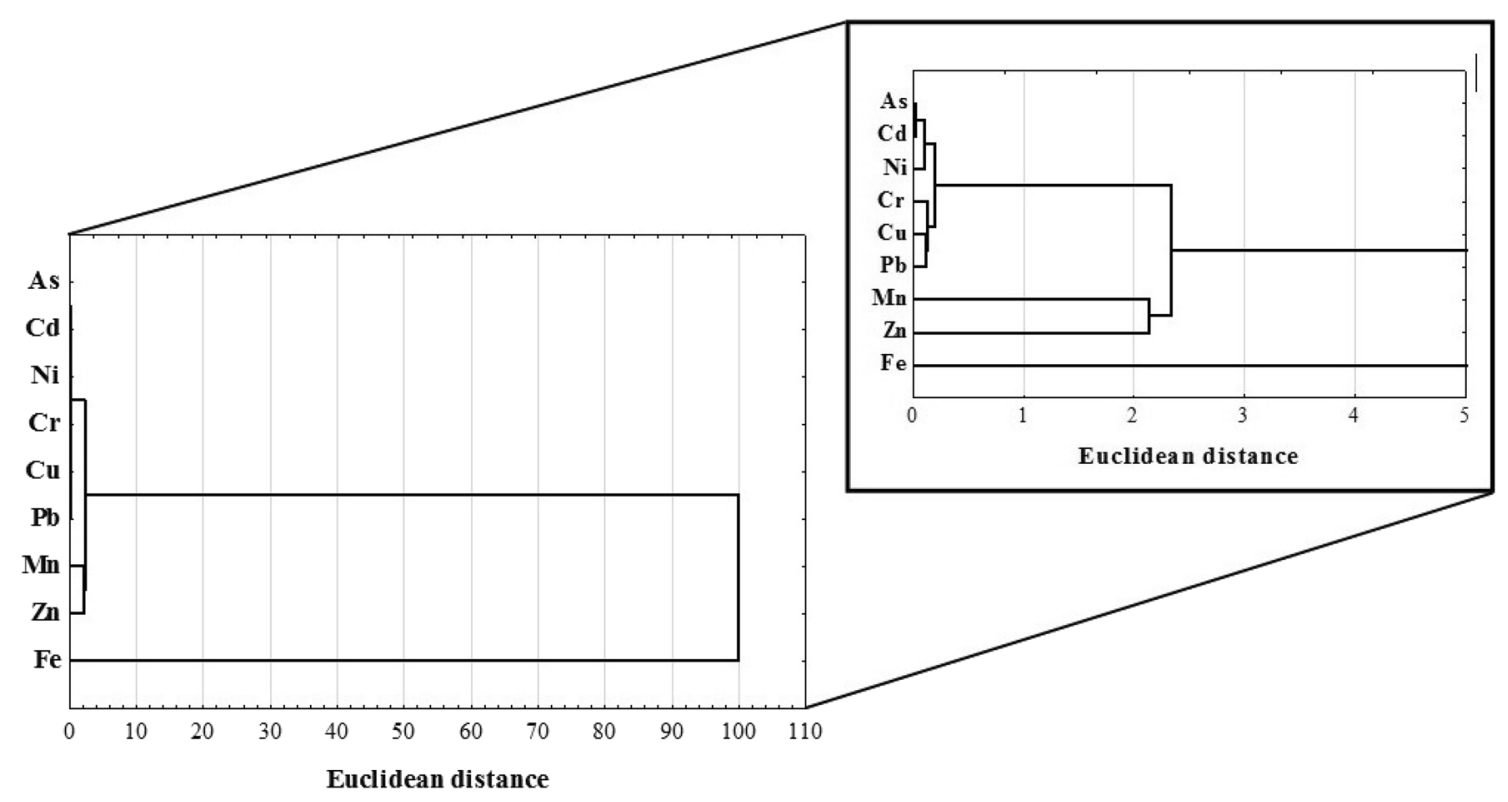

Fig. 5 Cluster analysis (CA) by Ward for Dzierżno Duże Reservoir 
$\mathrm{Ni}$ and $\mathrm{Pb}$, while the second one: $\mathrm{Mn}, \mathrm{Zn}$ and $\mathrm{Fe}$. Despite the similarities in the occurrence of toxic elements and changes in their concentrations reflected by the dendrogram, these two groups are strict different in term of Euclidean distances. Smaller distance was recorded for the elements from the first group, which means that they are probably strongly correlated. Moreover, to find similarities between measured parameters (potentially toxic elements), to determine the source of their origin, PCA analysis was carried out (Fig. 6). The obtained results indicated that examined elements could be grouped into a two principal components (PCs), which explained approx. $87.90 \%$ of total original data variance. The variance indicates the amount of total information presented by each element. The PC1 accounted for $74.70 \%$ of the total variance and was characterized by large fractions of $\mathrm{As}, \mathrm{Cd}, \mathrm{Cr}, \mathrm{Fe}, \mathrm{Ni}, \mathrm{Pb}$, and $\mathrm{Zn}$, suggesting of similar origin for these potentially toxic elements. While the second principal component (PC2) accounted for $13.20 \%$ of the total variance and included large fraction of Mn. Each parameter is represented by a vector. The direction and length of these vectors determine to which extent particular parameters affect the main components. Close position of two parameters indicates a strong correlation between them, for example: $\mathrm{Cr}$ and $\mathrm{Ni}$, whereas vectors perpendicular to each other indicate a lack of correlation, like in the case of $\mathrm{Mn}$ and $\mathrm{Ni}$. These results coincide with the conclusions resulting from the correlation analysis. Strong relationships between As, $\mathrm{Cd}, \mathrm{Cr}, \mathrm{Cu}, \mathrm{Ni}$, and $\mathrm{Pb}$, as well as small Euclidean distances and large fractions of these elements in PC1, indicate that they may originate from same contamination sources, probably anthropogenic. Moreover, PC1 includes a large fraction of $\mathrm{Fe}$ and $\mathrm{Zn}$, which occurrence may be closely related to overall emission of industrial pollutants in the studied area, discharged from: mine wastewater, municipal, industrial and post-mining waters, etc. Furthermore, the correlation matrix and PCA analysis confirm a strong relationship between Fe and other examined elements, despite of the results of CA analysis. Whereas, in case of $\mathrm{Mn}$, neither Pearson's correlation matrix nor PCA analysis, not confirm the strong relationship between $\mathrm{Mn}$ and $\mathrm{Zn}$ concentrations, even despite of a small Euclidean distance between these two elements. In addition, the content of Mn does not correlate with any of examined elements, except Al. Therefore, we can assume that manganese is probably of natural origin.

In conclusion, taking into account the level of industrialization of the studied area, it is very difficult to identify a single source for selected toxic elements in the bottom sediments of the Dzierżno Duże Reservoir. Moreover, the contamination and ecological risk levels, as well as the results of statistical analysis indicate that the major contaminants in the analyzed sediments, which pose the greatest threat to the environment, are $\mathrm{Cd}, \mathrm{Pb}, \mathrm{Zn}$, and $\mathrm{As}$. The conducted research indicates the necessity of combining chemical analyzes of sediments and ecological risk posed by toxic elements with in-depth statistical analysis, which will allow to determine a probable source of their origin.

\section{Conclusion}

In this study, different groups of indices were successfully used to assess the levels of contamination and ecological risk of nine metals ( $\mathrm{Al}, \mathrm{Cd}, \mathrm{Cr}, \mathrm{Cu}, \mathrm{Fe}, \mathrm{Mn}, \mathrm{Ni}, \mathrm{Pb}$, and $\mathrm{Zn}$ ) and one metalloid (As) in bottom sediments of the Dzierżno Duże Reservoir located in the key anthropogenic "hot spot" area. In general, the level of contamination and ecological risk associated with the presence of toxic elements in studied sediments, were very high. The highest risk poses $\mathrm{Cd}$, $\mathrm{As}, \mathrm{Zn}$, and $\mathrm{Pb}$. Taking into account high industrialization and urbanization of the research area, it can be assumed that toxic elements are probably of anthropogenic origin (except Mn). With reference to the above findings, it must be emphasized that comprehensive analysis of the contamination level and ecological risk of toxic elements in the bottom sediments constitute the basis in assessing the ecological state of water bodies. This is particularly important in case of reservoirs located in the key anthropogenic "hot spot" areas such as Upper Silesia, where all water bodies are of anthropogenic origin. It should be note that water bodies are an integral part of ecological networks in urban and industrial areas and they have important economic, environmental and landscape role. Therefore, for proper assessment of the contamination and ecological risk levels posed by metals

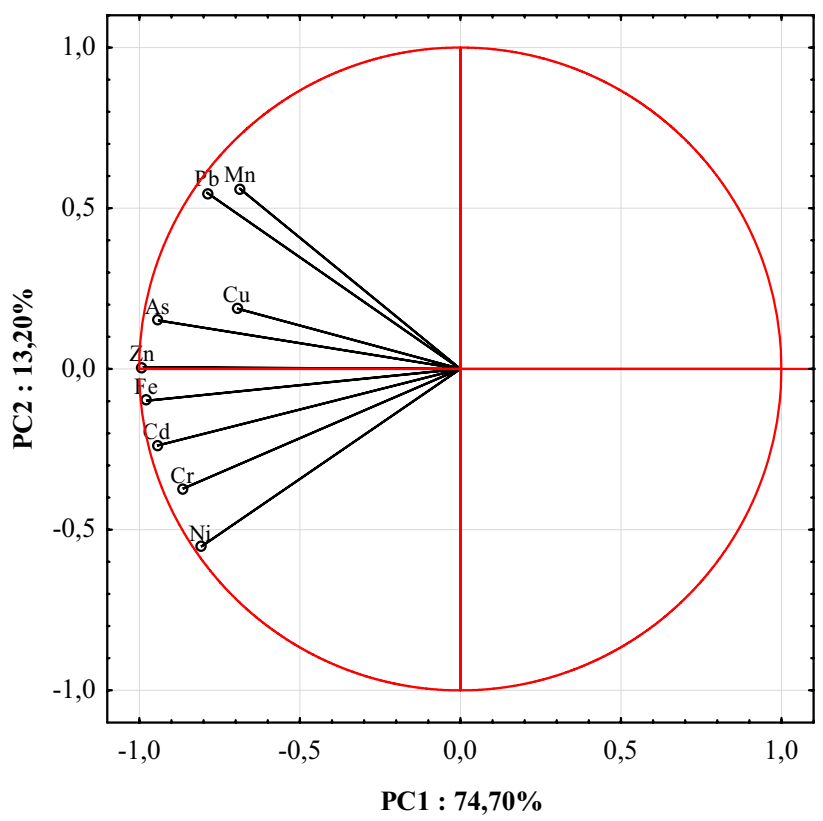

Fig. 6 Results of PCA analysis for Dzierżno Duże Reservoir 
and metalloids, determination of their potential source of origin is necessary. In this case, detailed statistical analysis is required. The combination of the abovementioned components, allows an accurate assessment of the ecological status of water bodies.

Acknowledgements This work was supported by the National Fund for Environmental Protection and Water Management under the "Program for the reclamation of dam reservoirs in the catchment area of Kłodnica River" ("Program rekultywacji zbiorników zaporowych w zlewni Kłodnicy", in Polish), developed by the Institute of Environmental Engineering Polish Academy of Sciences in Zabrze, University of Silesia in Katowice, Institute for Ecology of Industrial Areas and Małopolska Grupa Geodezyjno-Projektowa S.A. for the Regional Water Management Board in Gliwice. We would like to thank the University of Silesia in Katowice, Institute for Ecology of Industrial Areas and Małopolska Grupa Geodezyjno-Projektowa S.A. for their support in the course of our work under the above Program. Many thanks to Joanna Kernert for the contribution in data capture necessary to develop the Program based on which this work was created.

Open Access This article is distributed under the terms of the Creative Commons Attribution 4.0 International License (http://creativeco mmons.org/licenses/by/4.0/), which permits unrestricted use, distribution, and reproduction in any medium, provided you give appropriate credit to the original author(s) and the source, provide a link to the Creative Commons license, and indicate if changes were made.

\section{References}

Avila-Pérez P, Balcázar M, Zarazúa-Ortega G, Barceló-Quintal I, Diaz-Delgado C (1999) Heavy metal concentrations in water and bottom sediments of a Mexican reservoir. Sci Total Environ 234:185-196

Baran A, Tarnawski M (2015) Assessment of heavy metals mobility and toxicity in contaminated sediments by sequential extraction and a battery of bioassays. Ecotoxicology 24(6):1279-1293

Baran A, Tarnawski M, Koniarz T (2016) Spatial distribution of trace elements and ecotoxicity of bottom sediments in Rybnik reservoir, Silesian-Poland. ESPR 23(17):17255-17268

Barbusiński K, Nocoń W (2011) Heavy metal compounds in the bottom sediments of the river Klodnica (Upper Silesia). Ochrona Środowiska 33(1):13-17

Bartoszek L, Koszelnik P, Gruca-Rokosz R, Kida M (2015) Assessment of agricultural use of the bottom sediments from eutrophic Rzeszów reservoir. Rocznik Ochrona Środowiska 17:396-409

Bojakowska I (2001) Criteria of assessment pollution of water sediments. Polish Geo Rev 49(3):213-219

Colella A, D‘Orsogna MR (2014) Hydrocarbon contamination in waters and sediments of the Pertusillo freshwater reservoir, Val d'Agri, Southern Italy. Fresenius Environ Bull 23(12 B):3286-3295

Dąbrowska L (2011) Speciation of heavy metals in bottom sediments of the Kozłowa Góra Reservoir. Ochrona Środowiska i Zasobów Naturalnych 49:354-364

Devanesan E, Suresh Gandhi M, Selvapandiyan M, Senthilkumar G, Ravisankar R (2017) Heavy metal and potential ecological risk assessment in sediments collected from Poombuhar to Karaikal Coast of Tamilnadu using Energy dispersive X-ray fluorescence (EDXRF) technique. Beni-Suef Univ J Basic Appl Sci 6(3):285-292
García-Ordiales E, Esbrí JM, Covelli S, Lopez-Berdonces MA, Higueras PL, Loredo J (2016) Heavy metal contamination in sediments of an artificial reservoir impacted by long-term mining activity in the Almadén mercury district (Spain). ESPR 23(7):6024-6038

Ghaleno OR, Sayadi MH, Rezaei MR, Kumar CNP, Somashekar RK, Nagaraja BC (2015) Potential ecological risk assessment of heavy metals in sediments of water reservoir case study: Chah Nimeh of Sistan. Proc Int Acad Ecol Environ Sci 5(4):89-96

Godwin A, Oghenekohwiroro E, Funso A, Olaniyi O (2015) Using $\mathrm{EF}, \mathrm{PLI}$ and Igeo for the assessment of heavy metal pollution and sediment quality of Asejire Reservoir, southwest Nigeria. IJEPR 3(4):77-90

Hakanson L (1980) Ecological risk index for aquatic pollution control, a sedimentological approach. Water Res 14(8):975-1001

Jaguś A, Rzętała MA, Rzętała M (2013) Assessment of sediment contamination in water reservoirs in the aspect of land use. Proc EC Opole 7(13):49-355

Kabata-Pendias A (2011) Trace elements in soils and plants, 4th edn. Taylor \& Francis, London

Kostecki M, Suschka J (2013) The successful results of Pławniowice reservoir (Upper Silesian Region-South of Poland) restoration by hypolimnetic withdrawal. Arch Environ Prot 39(1):17-25

Lee PK, Kang MJ, Yu S, Ko KS, Ha K, Shin SC, Park JH (2017) Enrichment and geochemical mobility of heavy metals in bottom sediment of the Hoedong reservoir, Korea and their source apportionment. Chemosphere 184:74-85

Loska K, Wiechuła D (2003) Application of principal component analysis for the estimation of source of heavy metal contamination in surface sediments from the Rybnik Reservoir. Chemosphere 51(8):723-733

Macdonald DD, Ingersoll CG, Berger TA (2000) Development and evaluation of consensus-based sediment quality guidelines for freshwater ecosystems. Arch Environ Con Tox 39(1):20-31

Milošković A, Branković S, Simić V, Kovačević S, Cirković M, Manojlović D (2013) The accumulation and distribution of metals in water, sediment, aquatic macrophytes and fishes of the Gruža Reservoir. Serbia. Bull Environ Contam Toxicol 90:563-569

Müller G (1969) Index of geoaccumulation in sediments of the Rhine River. Geo J 2(3):108-118

Piwińska D, Gruca-Rokosz R, Bartoszek L, Czarnota J (2018) Spatial diversity characterising certain chemical substances in sediments of Besko reservoir. J Ecol Eng 19(1):104-112

PN-EN 13657 (2006) Characterization of waste. Digestion for subsequent determination of aqua regia soluble portion of elements

PN-EN ISO 11885 (2009) Water quality-determination of selected elements by inductively coupled plasma optical emission spectrometry (ICP-OES)

PN-ISO 11465 (1999) Soil quality-determination of dry matter content of soil and water in soil on a dry matter of soil-Weight method

Program for the reclamation of dam reservoirs in the catchment area of Kłodnica River (2016) ("Program rekultywacji zbiorników zaporowych w zlewni Kłodnicy” 2016, in Polish), Institute of Environmental Engineering Polish Academy of Sciences in Zabrze, University of Silesia in Katowice and Institute for Ecology of Industrial Areas and Małopolska Grupa Geodezyjno-Projektową S.A. for the Regional Water Management Board in Gliwice, pp 1-391

Research Procedure "The application of inductively coupled plasma mass spectrometry in water quality studies", 4th edition (10.02.2016); Institute of Environmental Engineering (Polish Academy of Sciences in Zabrze) own procedure according to PN-EN ISO 17294:2007 Water quality. Application of inductively coupled plasma mass spectrometry (ICP-MS). Part 1: General guidelines 
Rozpondek K, Rozpondek R, Pachura P (2017) Characteristics of spatial distribution of phosphorus and nitrogen in the bottom sediments of the water reservoir Poraj. J Ecol Eng 18(4):178-184

Rzętała M (2016) Accumulation of trace elements in bottom sediments of the Otmuchów and Dzierżno Duże Reservoirs-Oder River Basin, Southern Poland. Acta Geographica Silesiana 22:65-76

Rzymski P, Niedzielski P, Poniedziałek B, Klimaszyk P (2014) Bioaccumulation of selected metals in bivalves (Unionidae) and Phragmites australis inhabiting a municipal water reservoir. Environ Monit Assess 186:3199-3212

Sakan SM, Djordjevic DS, Manojlovic DD, Polic PS (2009) Assessment of heavy metal pollutants accumulation in the Tisza river sediments. J Environ Manage 90:3382-3390

Saleem M, Iqbal J, Shah MH (2015) Geochemical speciation, anthropogenic contamination, risk assessment and source identification of selected metals in fresh water sediments-a case study from Mangla Lake, Pakistan. Environ Nano Monit Manag 4:27-36

Siebielec S, Siebielec G, Smreczak B (2015) Contamination of bottom sediments in the rivers and water reservoirs (Zanieczyszczenia osadów dennych rzek i zbiorników wodnych). Studia i Reporty IUNG-PIB 46(20):163-181

Sivakumar S, Chandrasekaran A, Balaji G, Ravisankar R (2016) Assessment of heavy metal enrichment and the degree of contamination in coastal sediment from South East Coast of Tamilnadu, India. J Heavy Metal Toxicity Dis 1(2:11):1-8

Smal H, Ligęza S, Wójcikowska-Kapusta A, Baran S, Urban D, Obroślak R, Pawłowski A (2015) Spatial distribution and risk assessment of heavy metals in bottom sediments of two small dam reservoirs (south-east Poland). Arch Environ Protect 41(4):67-80

Szydłowski K, Rawicki K, Burczyk P (2017) The content of heavy metals in bottom sediments of the watercourse in agricultural catchment on the example of the river Gowienica. Ecol Eng 18(4):218-222

Wardhani E, Rossmini D, Notodarmojo S (2017) Status of heavy metal in sediment of Saguling Lake, West Java. IOP Conf Ser Earth Environ Sci 60:012035. https://doi.org/10.1088/17551315/60/1/012035

Wedepohl KH (1995) The composition of the continental crust. Geochim Cosmochim Acta 59:1217-1232

Widziewicz K, Loska K (2012) Multivariate statistical analyses on arsenic occurrence in Rybnik Reservoir. Arch Environ Prot 38(2):11-23

Wu B, Wang G, Wu J, Fu Q, Liu C (2014) Sources of heavy metals in surface sediments and an ecological risk assessment from two adjacent plateau reservoirs. PLoS One 9(7):e102101. https://doi. org/10.1371/journal.pone.0102101

Zemełka G, Szalińska E (2017) Heavy metal contamination of sediments from recreational reservoirs of urban areas and its environmental risk assessment. EPE 20(1):131-145

Zhao S, Feng C, Yang Y, Niu J, Shen Z (2012) Risk assessment of sedimentary metals in the Yangtze Estuary: new evidence of the relationships between two typical index methods. J Hazard Mater 241-242:164-172

Publisher's Note Springer Nature remains neutral with regard to jurisdictional claims in published maps and institutional affiliations. 